\section{The Treatment of Burns}

(Abstracted from a letter dated 10th December, 1946, from Dr. G. P. Arnold to the Editor, The Medical Journal of Australia, published in the Medical Journal of Australia, 28th December, 1946, p. 918)

THE author recommends egg albumin for all types of burns and in all positions.

The history is, that a small boy was sent in to him from the outlying farm districts with second degree burns of the face. He had been annointed by his grandmother with white of egg which was powdered with cornflour. As he seemed comfortable he did not interfere with his lesion in any way and in ten days the boy returned home completely healed and without any scars.

For this the author received great credit, and therefore felt that the treatment at least merited another trial. In any case of burns he anæsthetizes with 'Evipan Sodium' or ether, cleanses the area of all foreign substances, or loose skin or blisters with wool swabs saturated with ether and applies a single layer of gauze which has been drawn through egg albumen, flattening the gauze out gradually so that no air bubbles are present. This is allowed to dry, and the process is sometimes assisted by artificial heat.

If the original dressing adheres, as it usually does, it is left until it spontaneously peels off, all loose pieces being snipped away with sharp scissors and no further dressings applied. Any moisture appearing through the dressing is powdered twice daily with oleate of zinc and no attempt is made to evacuate any exudate which may collect beneath the gauze.

Of late he has been dusting the raw burnt surfaces with penicillin and sulphanilamide before application of the albumen, but does not consider this to be necessary, as it is only a balm to his conscience and not to the patient. He has no complaints made to him of pain and very seldom had he had to use a sedative.

In twenty-five years he has not had to use a skin graft except in two cases, and these were due to the patients concerned interfering with the artificial scab.

\section{Reviews}

HANDBOOK OF OPHTHALMOLOGY.-BY Everett $L$. Goar, A.B., M.D., F.A.C.S. 1948. The C. v. Mosby Company, St. Louis. Pp. 166 with 48 textillustrations and 7 coloured plates.

THIs book has been written with the idea that there is too much matter in most textbooks designed for Junior Medical Students. The author has attempted to 'put down the essentials that a student or general physician may grasp'. The book does not really fulfil the intentions of the author and shows considerable lack of balance between essentials and rareties. For example, the extremely common and important condition of angular conjunctivitis only gets two lines and yet the rare Sjogren's Syndrome receives eighteen lines. Trachoma is not illustrated and yet membranous conjunctivitis is given a picture. Treatment is not sufficiently dealt with. Operations are mentioned so briefly and-not illustrated at all, that it is very difficult to understand the text.

$$
\text { E. J. S. }
$$

AIDS TO OPHTHALMOLOGY.-By P. McG. Moffatt, M.D. (Lond.), M.R.C.P., F.R.C.S. (Eng.), D.O.M.S. 1948. Tenth Editlon. Balllière, TIndall and Cox, London. Pp. viil plus 266 with 118 Illustrations. Price, 6s. 6d.

THIs book, the first edition of which was published in 1910,' is one of the well known 'Students' Aid
Series'. Owing to the death of $\mathrm{Mr}$. Bishop Harman it is now edited and has been brought up to date by Mr. P. McG. Moffatt. Like all the volumes of this series it is rather too condensed for the beginner and too sketchy for the more advanced student. It is, however, an excellent revision book for those with already some practical knowledge of ophthalmology.

\section{E. J. S.}

\section{PRINCIPLES GOVERNING EYE OPERATING ROOM} PROCEDURES.-By Emma I. Clevenger; R.N. 1948. The C. V. Mosby Company, St. Louis. Pp. 215. Illustrated.

THE book is written by a Nursing Sister who has worked for many years in charge of the operating theatre of the New York Eye Infirmary. The title of the book is most misleading. Few principles are discussed. Miss Clevenger states dogmatically what technique is used in the theatre of the New York Eye Infirmary. The book consists largely of lists of instruments used by the various surgeons to the hospital for various operations. This eventually becomes ludicrous when we read a list of 34 instruments used by Dr. Berens for combined cataract extraction, followed by the details of the instruments used by no less than eleven other surgeons, each of whom is mentioned by name. When one reads under the sub-heading Ophthalmoscope.- This is a very delicate instrument. The handle is fitted with two Ever Ready batteries' one gets an idea of the general standard displayed. The book will be of interest to any nurse who may have to work in the theatre of the New York Eye Infirmary.

\section{E. J. S.}

NUTRITIONAL DISEASES IN INDIA: DESCRIBED FOR STUDENTS AND PRACTITIONERS.-BY R. Passmore, M.A., D.M. (Oxford), Captaln, I.M.s. 1948. U. N. Dhur and Sons, Limited, Calcutta. Pp. vill plus 126. Illustrated. Price, Rs. 10

THIs book gives a practical account of nutritional diseases as they present themselves to practitioners in India. It is the result of the author's long experience acquired while on the staff of the Indian Research Fund Association Laboratories at Coonoor and on active service with the Indian Army during the war. In order to make the book really practical he has cut down the chemical and pathological aspects of the subject to a minimum and stressed on clinical, as opposed to laboratory diagnosis. He describes the signs and symptoms of malnutrition and deficiency diseases, so that these conditions can be clinically diagnosed. Accepted and practical methods of treatment are given. There are five useful appendices giving: (1) tables of food analysis, (2) summary of dietary requirements, (3) properties of important vitamins, (4) diet-scales in Indian military hospitals and (5) menu of a special invalid kitchen.

The book makes no pretence to be a complete monograph on the subject, but it has the merit of being comprehensive and fairly up to date. It should be useful to medical students and practitioners in India.

$$
\text { R. N. C. }
$$

MODERN TRENDS IN DERMATOLOGY.-Edited by R. M. B. MacKenna, M.A., M.D. (Camb.), F.R.C.P. (Lond.). 1948. Butterworth and Company (Publishers), LImited, London. Pp. xiv plus 432. Illustrated. Price, Rs. 36-12. (Available from Messrs. Butterworth and Company, Limited, Calcutta)

THis is really a review of the study on dermatology in its various aspects by the workers in their respective spheres of research. The editor and the publishers deserve our thanks for getting together so many eminent authors.

The introduction by the editor is the best part of the book and is both interesting and instructive.

The size of the book might well have been reduced as many chapters repeat facts old and established. 